\title{
Does corporate social responsibility reduce financial distress? Evidence from emerging economy
}

\author{
Naeem Khan ${ }^{a^{*}}$, Qaisar Ali Malik ${ }^{\mathrm{b}}$, Ahsen Saghir ${ }^{\mathrm{a}}$, Muhammad Haroon Rasheed ${ }^{\mathrm{c}}$ and Muhammad \\ Husnain ${ }^{d}$
}

${ }^{a}$ Department of Business Administration, Foundation University Rawalpindi, Pakistan

${ }^{b}$ Associate Professor /Head of Department, Foundation University Rawalpindi, Pakistan

${ }^{c}$ Noon Business School, University of Sargodha, Pakistan

${ }^{d}$ Assistant Professor, Department of Business Administration, University of Sahiwal, Sahiwal 57000, Pakistan

\section{H R O N I C L E}

\begin{tabular}{l} 
Article history: \\
Received: December 25, 2020 \\
Received in revised format: \\
April 242021 \\
Accepted: April 24, 2021 \\
Available online: \\
April 24, 2021 \\
\hline Keywords: \\
CSR \\
FD \\
Z-Score \\
ZM-Score \\
Default Risk
\end{tabular}

\section{A B S T R A C T}

\begin{abstract}
This work investigates the relational behavior of corporate social responsibility (CSR) and its effect on firms' financial distress (FD). The population of the study consists of all the non-financial firms presently listed in the equity market of Pakistan. The yearly data set of 213 non-financial companies is selected from 2005 to 2017 with total observations of 2769 . The analysis of the study based on OLS regression, fixed effect, and random effect models. The study also uses the GMM technique to guard against potential problems of endogeneity and heteroskedasticity that arise from the use of panel data. Results indicate that higher investment in CSR leads to reduced/lower financial distress. It suggests that investment in CSR raises the reputation and creditworthiness of firms. Key findings are robust as confirmed by alternative proxies of financial distress. Overall findings advocate that CSR helps in reducing default risk or financial distress and creates a better corporate environment that ultimately improves organizations' economic outlook.
\end{abstract}

(C) 2021 by the authors; licensee Growing Science, Canada

\section{Introduction}

Corporate social responsibility is gaining repaid fame from both academia and corporate managers. It has become a topic of interest for researchers and policymakers in the last three decades. It is widely considered an instrument to attract investors and maintain better relations with its stakeholders (Yang, Chang, Chen, \& Shiu, 2019). Over time, debate on CSR and exploration of its linkages with other variables of economics and finance increased impressively (Boubaker, Cellier, Manita, \& Saeed, 2020). The popularity of CSR is on the rise as modern firms are now actively considering CSR as an effective tool that connects them and strengthens their bond with stakeholders. Corporations and researchers are convinced to conduct studies on the association of CSR by adding other interconnected variables. Studies such as the effect of CSR on the firm profitability (Shen, Wu, Chen, \& Fang, 2016), the effect of corporate social responsibility (CSR) on the cost of capital stock (El Ghoul, Guedhami, Kwok, \& Mishra, 2011), does CSR improves creditworthiness? (Jiraporn, Jiraporn, Boeprasert, \& Chang, 2014), assessing downsize and upsize risk spillovers (Ameur, Jawadi, Jawadi, \& Cheffou, 2020), Investing in CSR translates into increased firm performance (Khan \& Malik, 2020; Lins, Servaes, \& Tamayo, 2017). These studies conclude that CSR positively associates with the multiple factors determining a firm's fate. CSR is a voluntary firm activity, it entirely depends on the organization's decision to practice it or not (Mackey, Mackey, \& Barney, 2007). Studies document that CSR is considered as one of the important and fundamental factors for the survival and growth of the firm (Hoi, Wu, \& Zhang, 2013). Moreover, investing in CSR activities may enable a firm to improve shareholders' wealth and reduce the chances of financial distress (Godfrey, 2005).

\footnotetext{
* Corresponding author.

E-mail address: lusmeiliaafrani@gmail.com (N. Khan) 
From the past few years, studies on the relationship of CSR and FD have attained greater attention among researchers, but the studies on this relationship are very few (Deegan, 2002). A recent study conducted on the relationship of CSR and FD finds a negative association between CSR and FD, study uses firms' life cycle stages as a moderating variable (Al-Hadi, Chatterjee, Yaftian, Taylor, \& Monzur Hasan, 2019). Financial distress is an unclear term; the literature uses failure, insolvency, bankruptcy, and default risk to attribute this term. When the return on investment (ROI) is less than the cost of equity/ capital, this is a situation of failure. The financially distressed firms may face difficulties to access external funding and are considered weaker at credit rating. Managers of these firms are forced to take additional risks than fewer distressed firms (Edwards, Schwab, \& Shevlin, 2013). Despite being a central and well-explored area of research, the association of CSR with financial distress remained less fortunate as literature reports very few studies on the said relation. However, both of these terms are explored in isolation (Deegan, 2002). One of the recent studies on CSR and credit availability shows that high involvement in CSR allows firms to gain more reputation that enables them to obtain less costly financing (Jiraporn et al., 2014). It can be said that there exists a positive association between CSR attributes and firm credit standards (Attig, El Ghoul, Guedhami, \& Suh, 2013). High ranking in CSR mitigates the default risk (Sun, Duong, \& Singh, 2014). If high CSR work does not result in any financial benefit to the company, every appeal is only moral preaching (Wang, Sewon, \& Claiborne, 2008). When it comes to the relationship between CSR and FD, the result is still debatable among classical theory and empirical research. According to the stakeholder theory, stakeholders include corporate shareholders, government agencies, environmental pressure groups, and creditors, etc., (Freeman, 1994; Khan \& Saghir, 2020). So, the increased social investment would strengthen stakeholder partnerships and help companies reduce their social expenses, resulting in improved net financial value (Wang et al., 2008). Likewise, signaling theory shows that transmitting CSR signals will produce favorable information that benefits the brand, boost the company's prestige, productivity and increase the company's credibility as well as financial return (Connelly, Certo, Ireland, \& Reutzel, 2011). The organization theory and shareholder theory, on the other hand, both introduced a different perspective. Shareholders can pay agency fees as a result of a company's corporate obligation. As a result, more CSR work could damage a company's core operations (Lu, Chau, Wang, \& Pan, 2014).

The above studies show that firms engaged actively in CSR practices hold a solid corporate image which mitigates chances of falling into default and can ultimately enjoy good credit ratings. On the other hand, Financial Distress provides more damaging results than corporate deterioration, and it is a late phase of corporate decline, resulting in bankruptcy (Platt \& Platt, 2002).CSR helps mitigate the risk of different types and improves credit ratings (Harjoto \& Laksmana, 2018). For instance, $\mathrm{Kim}, \mathrm{Li}$, and $\mathrm{Li}$ (2014) report, firms that invest in CSR are more transparent, face relatively less unpleasant events, and encounter a lower risk of share price crash. W. Sun and Cui (2014) document that involvement in CSR activities increases the firms' creditworthiness. This work is an attempt to explore the association of CSR and FD in Pakistan. To the best of the author's information, this work is the first effort to explore said association, with a more extensive data set comprising all nonfinancial companies listed at PSX. The remaining article is arranged as follows: Second section explains a review of the related literature. The third section of the paper explains research methodology, data, and tools used for analysis. The fourth section discusses the results of descriptive statistics, correlation analysis, OLS regression, fixed effect model, random effect model, and GMM technique. The fifth section explains the conclusion, limitation and future research area.

\section{Literature Review}

Literature on CSR and FD relationship shows that investment in social practices by firms tended to the decreased firm risk and improved the funding support environment, which can reduce distress (Boubaker et al., 2020). It debates that CSR adoption would benefit investors and firms and society at large (Becchetti, Ciciretti, \& Hasan, 2015). CSR activities are performed for the benefit of the organization, the benefit can be in the shape of increased shareholder wealth (Krüger, 2015), reduction in chances of firm default ( $\mathrm{Jo} \& \mathrm{Na}, 2012$ ), inexpensive access to financing (Cheng, Ioannou, \& Serafeim, 2014) and in the form of increased transparency of firms' image (Kim et al., 2014). Firms that invest in CSR activities most certainly disclose their CSR activities to become more transparent (Dhaliwal, Radhakrishnan, Tsang, \& Yang, 2012). As a result, higher levels of transparency, the asymmetry of information between firms and investors reduces. Therefore, it contributes to mitigates firm risk (Jo \& Na, 2012). The CSR is also used by managers as a moral tool for the achievement of multiple objectives i.e, to improve information transparency, to make strategies, to do philanthropic work, and to reduce firm default risk. While the manager also considers it as a strategic investment through which the company will benefit in the long run (Cai, Jo, \& Pan, 2012; Jensen \& Meckling, 1976). A firm's default risk can be associated with a firm's core operation as a consequence of internal as well as external factors that can influence the profitability of the firm. Changes in consumer demand may trigger a company's equity price to tumble. Since there is more demand, there will be less fear, and less demand means increased investors risk that they have to bear. In general, a firm risk is a mix of systematic and unsystematic risk. Systematic risks are often referred to as market risks because they affect a vast number of properties. Unsystematic risks, on the other hand, are often referred to as firm-specific, special risks since they concern just a limited amount of assets (Jo \& Na, 2012). Financial distress occurs when a firm is incapable of fulfilling its financial compulsions and is eventually forced to sell its financial properties at a huge discount (Shleifer \& Vishny, 1992). Financial distress can be costly not only in terms of high financing cost but in terms of loss of key customers/ suppliers and loss of qualified and trained staff, Companies must put efforts to reduce the risk of financial distress (Altman \& Hotchkiss, 2010). Weber (2008) reports that the tendency of a firm's default can be determined by the cash flows because adequate cash flows ease the firm operations and save from falling into the situation of financial distress. Pradhan and Nibedita (2019) document that the default risk is not only determined by the level of cash flows but also can be determined by the volatility of cash flows. Excessive volatility of cash flows brings a shortfall of cash and ultimately leads to financial distress. Financial distress forces firm managers to make such decisions that are 
value-enhancing and improve firm performance (Mitnick, 1975). It is essential for companies to come up with such financial policies to either reduce the monetary risk or to reduce the chances of falling into financial distress, and it can be slashed through better management of socially responsible activities (Jo \& Na, 2012). Firms that invest in socially responsible activities enjoy more creditworthiness (Jiraporn et al., 2014) and can have greater access to capital financing (Cheng et al., 2014). Investment in CSR activities stabilizes the financial performance of firms as it enhances the reputation and firm image in the society (Mitnick, 1975). Firms that are engaged in CSR activities get less costly equity funding plus reduced idiosyncratic risk (El Ghoul et al., 2011). CSR is a proxy to increase the governance quality, and companies which are involved in these practices are less likely to face monetary problems or financial distress (Attig \& Cleary, 2015). Trade-off theory suggests that a situation of continued financial distress can lead to bankruptcy of a firm (Zheng, Wang, \& Jiang, 2019). The relationship of CSR and FD have, however, gained the attention of researchers and firm managers, but the literature on the said relationship is still limited (Deegan, 2002; Taylor, Al-Hadi, Richardson, Alfarhan, \& Al-Yahyaee, 2019).

A study of the literature reveals, there exist fewer studies available to conclude the CSR activities and their influence on firms' risk profile (Hsu \& Chen, 2015). Generally, studies on the relationship between CSR and FD report a negative correlation. Companies that invest in CSR activities hold better association with important stakeholders i.e, creditors, employees, suppliers, and lenders which increases their performance (Godfrey, Merrill, \& Hansen, 2009). If investing in CSR reduces the chance of financial distress, then it will indirectly increase firm performance. CSR and FD are both important constructs in finance literature but are explored in isolation (Deegan, 2002).

\section{Research Methodology}

The data is gathered from the published financial reports of firms listed on the Stock exchange of Pakistan. The data set consists of only non-financial sector firms, whereas the financial sector firms are purposefully excluded due to their dissimilar characteristics of capital structure and reporting requirements. A yearly data set ranging from 2005 to 2017 is selected for analysis with data of 12 years. The data holds 2769 observations from 213 companies. For empirical analysis, this article uses the OLS model, random and fixed effect models on panel data of companies. Panel data method overcomes issues of both cross-sectional data and time-series data. The blend of cross-sectional data along with time-series data is advantageous for non-financial firms (Sarwar, Xiao, Husnain, \& Naheed, 2018). The current study also uses the GMM technique as it guards against potential problems of endogeneity and heteroskedasticity that arise from the use of panel data. In the study, two alternative proxies of financial distress are used for the robustness of results, i.e., the Altman Z-Score Model and the ZMscore of Zmijewski (1984). Whereas, CSR is measured through CSR monetary spending ratio. Consistent with prior work, the study uses a control variable that includes, Size, Age, Leverage, Tangibility, Slack and current Ratio (CA). A detailed explanation of dependent, independent variables, control variables along with measuring proxies is provided in Table 1.

Table 1

Measurement of variables

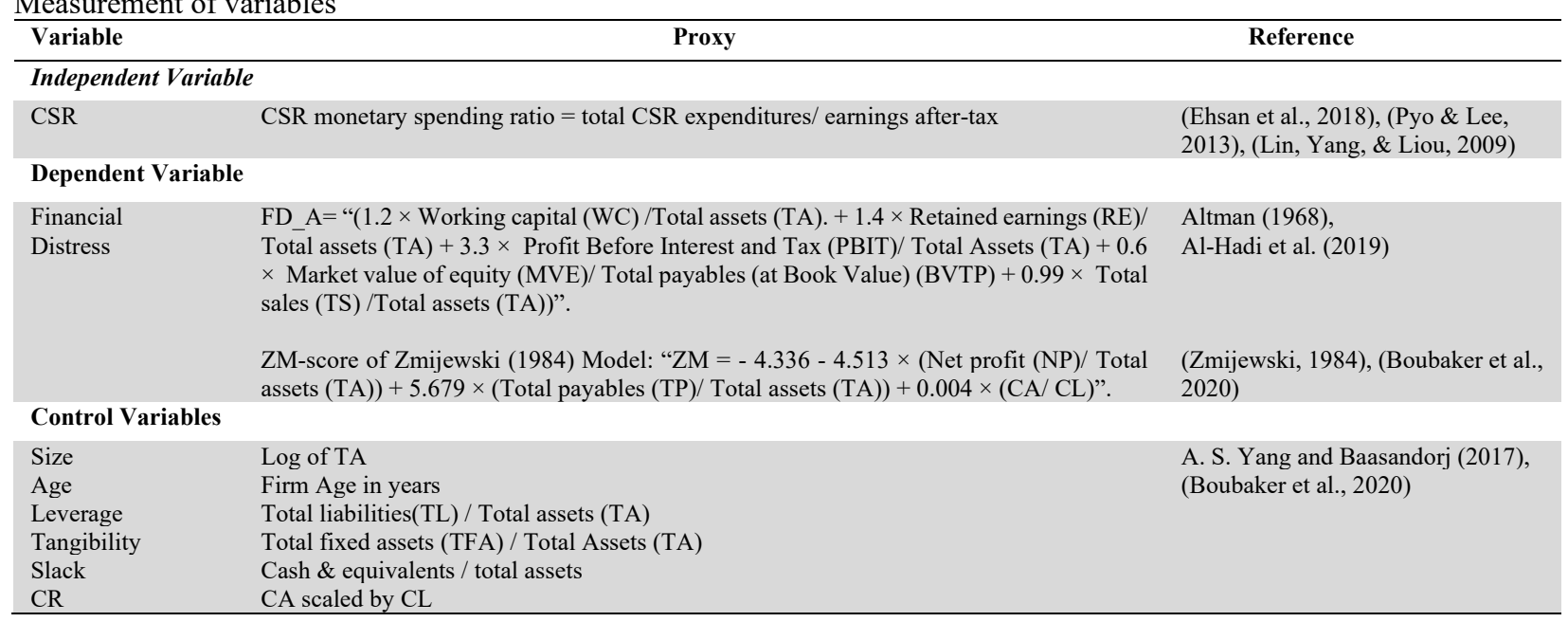

Econometric models of the study:

$$
\begin{array}{lll}
F D_{-} A_{i, t}=\beta_{0}+\beta_{1} C S R_{i, t}+\beta_{2} S I Z E_{i, t}+\beta_{3} A G E_{i, t}+\beta_{4} L E V_{i, t}+\beta_{5} S L A C K_{i, t}+\beta_{6} T A N G_{i, t}+\beta_{7} C R_{i, t}+\varepsilon_{i, t} & \text { Model } 1 \\
F D_{-} Z M_{i, t}=\beta_{0}+\beta_{1} C S R_{i, t}+\beta_{2} S I Z E_{i, t}+\beta_{3} A G E_{i, t}+\beta_{4} L E V_{i, t}+\beta_{5} S L A C K_{i, t}+\beta_{6} T A N G_{i, t}+\beta_{7} C R_{i, t}+\varepsilon_{i, t} & \text { Model } 2
\end{array}
$$

\section{Result and discussion}

\subsection{Statistics of descriptive analysis}

Table 2 represents statistics of descriptive analysis of the study using all variables. These statistics are estimated to get general data to feel and to check for any possible discrepancy. 
Results show that the values of all variables fall within acceptable limits. For conciseness, the detailed discussion of the selected variables is avoided.

Table 2

Descriptive statistics

\begin{tabular}{llllll}
\hline & Mean & Median & Max & Min & SD \\
\hline CSR & 0.023 & 0.006 & 0.575 & 0.000 & 0.053 \\
Z_SCORE & 1.207 & 1.054 & 5.195 & 0.003 & 0.791 \\
ZM_SCORE & -1.183 & -1.221 & 10.575 & -6.764 & 1.896 \\
SIZE & 15.257 & 15.078 & 20.257 & 8.536 & 1.572 \\
AGE & 35.572 & 32.000 & 95.000 & 1.000 & 16.021 \\
LEV & 0.592 & 0.587 & 2.970 & 0.004 & 0.295 \\
SLACK & 0.139 & 0.098 & 0.770 & 0.000 & 0.140 \\
TANG & 0.529 & 0.543 & 0.978 & 0.000 & 0.207 \\
CR & 1.375 & 1.099 & 5.945 & 0.018 & 2769 \\
\hline
\end{tabular}

\subsection{Correlation Analysis}

Table 3 represents the results of correlation statistics. The values of correlation results inform the association of the variables that can either be positive or negative or zero and on the strength. All the values in the given table are within acceptable limits, and there is no problem with multicollinearity. The relationship of CSR with Z-Score and ZM-Score is positive, as shown by their $r$ values $(0.052)$ and $(0.001)$, respectively. Results also disclose that the relationship of CSR to Z-Score and CSR to ZM Score is weak.

Table 3

The results of correlation statistics

\begin{tabular}{|c|c|c|c|c|c|c|c|c|c|}
\hline & CSR & Z_SCORE & ZM_SCORE & SIZE & $A G E$ & $L E V$ & SLACK & $T A N G$ & $C R$ \\
\hline CSR & 1 & & & & & & & & \\
\hline Z_SCORE & 0.052 & 1 & & & & & & & \\
\hline ZM_SCORE & 0.001 & -0.125 & 1 & & & & & & \\
\hline SIZE & -0.062 & -0.038 & -0.165 & 1 & & & & & \\
\hline AGE & -0.048 & 0.027 & -0.128 & 0.201 & 1 & & & & \\
\hline LEV & -0.019 & -0.047 & 0.967 & -0.147 & -0.132 & 1 & & & \\
\hline SLACK & -0.066 & 0.303 & -0.118 & 0.174 & 0.014 & -0.070 & 1 & & \\
\hline TANG & 0.078 & -0.474 & 0.199 & -0.024 & -0.122 & 0.141 & -0.593 & 1 & \\
\hline CR & -0.056 & 0.109 & -0.653 & 0.102 & 0.164 & -0.623 & 0.245 & -0.427 & 1 \\
\hline
\end{tabular}

This 3 reports the results of the correlation coefficients. The sample consists of 2769 observations from non-financial companies listed in PSX covering 213 companies for the period 2005 to 2017 . Table 1 reports the details and computations method of all the variables

\subsection{Regression Analysis}

\subsubsection{Effect of CSR on FD through ZM-Score model}

Table 4 represents the results of OLS regression, fixed effect model, random effect model, and GMM for ZM-score score model of financial distress. Table 4 also reports the coefficients, $t$-value, and $p$-value for all models. Results of the OLS model suggest the CSR has significant positive effects on FD $(\mathrm{P}<0.05)$. It means firms that practice CSR more can reduce their level of financial risk. The relationship of the ZM-score with SIZE is significantly negative $(\mathrm{P}<0.05)$. It suggests that companies are less exposed to financial distress as they are enjoying a better monetary and political environment. The relationship of ZM-score with AGE, LEV, and TANG is also significantly positive $(\mathrm{P}<0.05)$. However, the relationship of ZM-score with Slack and CR is insignificant. The value of Adj. $\mathrm{R}^{2}$ is $(0.32)$, which means 32 percent variance in the endogenous variable is due to the exogenous variables. The Probability value of the F-statistic is significant $(\mathrm{P}<0.05)$, which shows that the economic model is structurally fit.

The fixed-effect model shows that the effect of CSR is significant and positive on ZM-score $(\mathrm{P}<0.05)$, which shows that firms engaged in CSR practices can decrease their financial distress level. The relationship of ZM-score with SIZE is significantly negative $(\mathrm{P}<0.05)$, these companies are less exposed to default risk as they are enjoying a good economic and political environment. The relationship of ZM-score with LEV, Slack, and TANG is also significant $(\mathrm{P}<0.05)$. The relationship of the ZMscore with AGE and CR is insignificant $(\mathrm{P}>0.05)$. The value of Adj. $\mathrm{R}^{2}$ is $(0.36)$, which means 36 percent of the variance in the endogenous variable is due to the exogenous variables. The Prob. of F-statistic is significant $(\mathrm{P}<0.05)$, which indicates the economic model is a good fit. Results using the random-effect model suggest, the effect of CSR on the ZM-score is significantly positive $(\mathrm{P}<0.05)$, which shows that companies engaged in CSR practices are in the capacity to reduce their level of default risk. The relationship of ZM-score with SIZE, AGE, LEV, and TANG is significant. The relationship of ZM-score with Slack and CR is insignificant. The value of Adj. $\mathrm{R}^{2}$ is (0.29), which means 29 percent of the variance in the endogenous 
variable is due to the exogenous variables. The probability value of the F statistic is significant $(\mathrm{P}<0.05)$, indicating the goodness of the model. The results using the GMM model suggest that CSR is significantly and positively affecting ZM-score $(\mathrm{P}<0.05)$ which indicates that firms that are engaged in CSR-related work can reduce their level of financial distress, our findings are consistent with (Boubaker et al., 2020). The value of Adj. $\mathrm{R}^{2}$ is $(0.41)$, which means 41 percent variance in the endogenous variable is due to the exogenous variables.

Table 4

The effect of CSR on financial distress using ZM-Score model

\begin{tabular}{|c|c|c|c|c|c|c|c|c|c|c|c|c|}
\hline \multirow[b]{2}{*}{ Var. } & \multicolumn{3}{|c|}{ OLS } & \multicolumn{3}{|c|}{$\begin{array}{c}\text { Fixed } \\
\text { Effect Model }\end{array}$} & \multicolumn{3}{|c|}{$\begin{array}{c}\text { Random } \\
\text { Effect Model }\end{array}$} & \multicolumn{3}{|c|}{ GMM } \\
\hline & Coef & t-Stats & Prob & Coef & t-Stats & Prob & Coef & t-Stats & Prob & Coef & t-Stats & Prob \\
\hline CSR & 1.19 & 0.42 & 0.01 & 1.88 & 0.44 & 0.00 & 1.70 & 0.42 & 0.00 & 2.16 & 1.07 & 0.05 \\
\hline SIZE & -0.05 & 0.01 & 0.00 & -0.03 & 0.02 & 0.08 & -0.02 & 0.01 & 0.00 & -0.05 & 0.01 & 0.00 \\
\hline AGE & 0.00 & 0.00 & 0.00 & 0.00 & 0.00 & 0.42 & 0.00 & 0.00 & 0.00 & 0.00 & 0.00 & 0.05 \\
\hline LEV & 6.14 & 0.06 & 0.00 & 6.39 & 0.07 & 0.00 & 6.29 & 0.06 & 0.00 & 5.89 & 0.07 & 0.00 \\
\hline SLACK & -0.08 & 0.06 & 0.23 & -0.19 & 0.09 & 0.04 & -0.14 & 0.08 & 0.07 & -0.39 & 0.07 & 0.00 \\
\hline TANG & 0.34 & 0.05 & 0.00 & 0.34 & 0.07 & 0.00 & 0.36 & 0.06 & 0.00 & 0.00 & 0.93 & 0.35 \\
\hline CR & -0.02 & 0.02 & 0.21 & 0.00 & 0.02 & 0.82 & -0.01 & 0.02 & 0.70 & 0.00 & 0.95 & 0.34 \\
\hline Adjusted $\mathrm{R}^{2}$ & & & 0.32 & & 0.36 & & & 0.29 & & & 0.41 & \\
\hline F-statistic & & & 3406 & & 165 & & & 2558 & & & & \\
\hline Prob. (F-stats) & & & 0.00 & & 0.00 & & & 0.00 & & & & \\
\hline Prob. of J-stats & & & & & & & & & & & 0.70 & \\
\hline
\end{tabular}

Table 4 reports OLS regression, Fixed effect model, Radom effect model and GMM models. It shows the values of coefficients, t-values and p-values for all the variables. High ZM-Score value corresponds to low level of financial distress.

\subsubsection{Effect of CSR on FD through Z-Score model}

Table 5 represents the results of OLS regression, fixed effect model, random effect model, and GMM for Altman Z score model of financial distress. The table also reports the coefficients, t-value, and p-value for all models. Results of the OLS model suggest that CSR affects significantly and positively FD $(\mathrm{P}<0.05)$. It means firms that are engaged in CSR work can reduce their financial distress level. The Z-score relationship with SIZE is significantly negative $(\mathrm{P}<0.05)$. This indicates that they are not exposed to financial distress. These firms are enjoying an excellent economic and political environment. The relationship of the $\mathrm{Z}$-score with AGE and Slack is significantly positive $(\mathrm{P}<0.05)$. However, the relationship of the $\mathrm{Z}$-score with LEV, TANG, and CR is significantly negative $(\mathrm{P}<0.05)$. The value of Adj. $\mathrm{R}^{2}$ is $(0.491)$, which means 49.1 percent of the variance in the endogenous variable is due to the exogenous variables. The probability value of the F-statistic is significant $(\mathrm{P}<0.05)$, which indicates that the econometric model is a good fit for data. Fixed-effect model suggests CSR is significantly positively affecting $\mathrm{Z}$-score $(\mathrm{P}<0.05)$. This shows companies that are actively conducting CSR work can decrease their financial distress level. The relationship of $Z$-score with SIZE is significantly negative $(\mathrm{P}<0.05)$, which means these firms are less likely to fall into financial distress. The relationship of $\mathrm{Z}$-score with AGE and Slack is significantly positive $(\mathrm{P}<0.05)$. The relationship of the Z-score with LEV, TANG, and CR is significantly negative $(\mathrm{P}<0.05)$. The value of Adj. $\mathrm{R}^{2}$ is $(0.794)$, which means 79.4 percent of the variance in the endogenous variable is due to the exogenous variables. The probability value of the F-statistic is significant $(\mathrm{P}<0.05)$ which indicates that the econometric model is a good fit. Random effect model suggests CSR significantly positively affecting Z-score $(\mathrm{P}<0.05)$, which shows that companies practicing CSR can reduce their financial distress level. The relationship of the Z-score with AGE and Slack is Positive. The relationship of Z-score with SIZE, Lev, Tang, and CR are negative. The value of Adj. $\mathrm{R}^{2}$ is $(0.138)$, which means 13.80 percent of the variance in the endogenous variable is due to the exogenous variables. The probability of $\mathrm{F}$ statistic is significant $(\mathrm{P}<0.05)$, which indicates that the econometric model is a good fit. The results using the GMM model suggest that the CSR on Z-score is significantly positive $(\mathrm{P}<0.05)$, which shows that companies that are actively pursuing CSR work are in a position to decrease their financial distress level, the findings are consistent with(Gangi, Meles, Monferrà, \& Mustilli, 2018) and (Boubaker et al., 2020). The value of Adj. $\mathrm{R}^{2}$ is (0.207), which means 20.70 percent variance in the endogenous variable is due to the exogenous variables.

Table 5

The effect of CSR on financial distress using Z-Score model

\begin{tabular}{|c|c|c|c|c|c|c|c|c|c|c|c|c|}
\hline \multirow[b]{2}{*}{ Var. } & \multicolumn{3}{|c|}{ OLS } & \multicolumn{3}{|c|}{$\begin{array}{c}\text { Fixed } \\
\text { Effect Model }\end{array}$} & \multicolumn{3}{|c|}{$\begin{array}{c}\text { Random } \\
\text { Effect Model }\end{array}$} & \multicolumn{3}{|c|}{ GMM } \\
\hline & Coef & $t$-Stats & Prob & Coef & t-Stats & Prob & Coef & $t$-Stats & Prob & Coef & $t$-Stats & Prob \\
\hline CSR & 0.48 & 4.01 & 0.00 & 0.02 & 0.15 & 0.88 & 1.22 & 2.91 & 0.00 & 1.19 & 0.56 & 0.03 \\
\hline SIZE & -0.05 & -10.1 & 0.00 & -0.25 & 0.02 & 0.00 & -0.15 & 0.03 & 0.00 & -0.01 & 0.01 & 0.04 \\
\hline AGE & 0.00 & 2.46 & 0.01 & 0.01 & 0.00 & 0.00 & 0.00 & 0.00 & 0.08 & 0.00 & 0.00 & 0.23 \\
\hline LEV & -0.20 & -6.34 & 0.00 & -0.67 & 0.06 & 0.00 & -0.58 & 0.10 & 0.00 & -0.17 & 0.09 & 0.08 \\
\hline SLACK & 0.15 & 1.97 & 0.05 & 0.73 & 0.11 & 0.00 & 0.74 & 0.20 & 0.00 & -0.23 & 0.25 & 0.36 \\
\hline TANG & -1.78 & -37.6 & 0.00 & -0.63 & 0.08 & 0.00 & -0.76 & 0.14 & 0.00 & -2.48 & 0.10 & 0.00 \\
\hline CR & -0.11 & -10.3 & 0.00 & -0.04 & 0.02 & 0.02 & -0.04 & 0.03 & 0.10 & -0.22 & 0.03 & 0.00 \\
\hline Adjusted $\mathrm{R}^{2}$ & & & 0.49 & & & 0.79 & & & 0.14 & & & 0.21 \\
\hline F-statistic & & & 382.7 & & & 42.6 & & & 64.1 & & & \\
\hline Prob. (F-stats) & & & 0.00 & & & 0.00 & & & 0.00 & & & \\
\hline Prob. of J-stats & & & & & & & & & & & & 2.04 \\
\hline
\end{tabular}


Table 5 reports OLS regression, Fixed-effect, Rnadom-effect and model GMM models. It shows the values of coefficients, tvalues, and p-values for all the variables. Z-score value informs on financial distress, a high value corresponds to low financial distress whereas a low value indicates otherwise.

\section{Conclusion}

To explore the answer, whether firms' investment in CSR work helps in reducing their financial distress? For this purpose, this study undertakes a sample of 213 non-financial companies with 2769 firm's year observations. For analysis study uses OLS regression, random effect model, fixed-effect model and GMM model. The findings of this study recommend that companies with high CSR activities have low levels of financial distress. In other words, companies with effective corporate social responsibility (CSR) plans can reduce their financial risk or risk of default. These findings are robust as alternative proxies of financial distress are utilized for testing. Similar findings are obtained from alternative methods of analyses of OLS regression, fixed effect model, random effect model, and GMM. Which confirms CSR can significantly reduce financial distress. Prior researchers are also in conformity, a firm can reduce its business risk by using proper management of social and environmental issues (Jo \& Na, 2012). Socially responsible firms enjoy better creditworthiness (Jiraporn et al., 2014), these firms enjoy better access to external financing (Cheng et al., 2014). Overall, findings suggest that the firms with a high level of CSR performance enjoy a lower level of financial distress, suggesting that engagement in CSR helps to avoid financial defaults. Hence, it can be safely concluded that involvement in CSR activities leads to a better corporate environment. It also increases a financially stable environment and avoids financial crises. Findings also suggest that there is a need for regulatory reforms to promote CSR practices in Pakistan as CSR is a win-win situation. Efforts in the investment in CSR activities will not only benefit the social development but also enable firms to avoid financial distress and improve corporate performance. Therefore, policymakers should pay attention to CSR-related practices to avoid financial risk. The current study also has two limitations. First, the sample is based only on non-financial sector companies listed on Pakistan Stock Exchange (PSX). However, the financial sector could not be included in the study sample. As financial sector companies hold several characteristics that are dissimilar from non-financial such as reporting requirements, accounting period, etc. Second, non-financial firms which are currently not listed in any of the stock exchange were not added in the study sample as the data is accessible.

Future researches can also focus on other dimensions of CSR and may include other relevant mediating variables in the relationship of CSR and FD. Upcoming researches may also explore other proxies of financial distress; an effort should also be devoted to developing a new model for the measurement of financial distress so a more accurate prediction of default risk may be achieved. Future research may include a relatively larger data set consisting of a data set based on developing countries for generalization of findings. Future work may consider the financial sector to see whether similar findings hold in the financial industry or not?

\section{References}

Al-Hadi, A., Chatterjee, B., Yaftian, A., Taylor, G., \& Monzur Hasan, M. (2019). Corporate social responsibility performance, financial distress and firm life cycle: evidence from Australia. Accounting \& Finance, 59(2), 961-989.

Altman, E. I. (1968). Financial ratios, discriminant analysis and the prediction of corporate bankruptcy. The journal of finance, 23(4), 589-609.

Altman, E. I., \& Hotchkiss, E. (2010). Corporate financial distress and bankruptcy: Predict and avoid bankruptcy, analyze and invest in distressed debt (Vol. 289): John Wiley \& Sons.

Ameur, H. B., Jawadi, F., Jawadi, N., \& Cheffou, A. I. (2020). Assessing downside and upside risk spillovers across conventional and socially responsible stock markets. Economic Modelling, 88, 200-210.

Attig, N., \& Cleary, S. (2015). Managerial practices and corporate social responsibility. Journal of Business Ethics, 131(1), 121-136.

Attig, N., El Ghoul, S., Guedhami, O., \& Suh, J. (2013). Corporate social responsibility and credit ratings. Journal of Business Ethics, 117(4), 679-694.

Becchetti, L., Ciciretti, R., \& Hasan, I. (2015). Corporate social responsibility, stakeholder risk, and idiosyncratic volatility. Journal of Corporate Finance, 35, 297-309.

Boubaker, S., Cellier, A., Manita, R., \& Saeed, A. (2020). Does corporate social responsibility reduce financial distress risk? Economic Modelling.

Cai, Y., Jo, H., \& Pan, C. (2012). Doing well while doing bad? CSR in controversial industry sectors. Journal of Business Ethics, 108(4), 467-480.

Cheng, B., Ioannou, I., \& Serafeim, G. (2014). Corporate social responsibility and access to finance. Strategic Management Journal, 35(1), 1-23.

Connelly, B. L., Certo, S. T., Ireland, R. D., \& Reutzel, C. R. (2011). Signaling theory: A review and assessment. Journal of Management, 37(1), 39-67.

Deegan, C. (2002). Introduction: The legitimising effect of social and environmental disclosures-a theoretical foundation. Accounting, Auditing \& Accountability Journal, 15(3), 282-311.

Dhaliwal, D. S., Radhakrishnan, S., Tsang, A., \& Yang, Y. G. (2012). Nonfinancial disclosure and analyst forecast accuracy: International evidence on corporate social responsibility disclosure. The Accounting Review, 87(3), 723-759.

Edwards, A., Schwab, C., \& Shevlin, T. (2013). Financial constraints and the incentive for tax planning. Paper presented at the 2013 American Taxation Association midyear meeting: New faculty/doctoral student session. 
Ehsan, S., Nazir, M. S., Nurunnabi, M., Raza Khan, Q., Tahir, S., \& Ahmed, I. (2018). A multimethod approach to assess and measure corporate social responsibility disclosure and practices in a developing economy. Sustainability, 10(8), 2955.

El Ghoul, S., Guedhami, O., Kwok, C. C., \& Mishra, D. R. (2011). Does corporate social responsibility affect the cost of capital? Journal of Banking \& Finance, 35(9), 2388-2406.

Freeman, R. E. (1994). The politics of stakeholder theory: Some future directions. Business ethics quarterly, $409-421$.

Gangi, F., Meles, A., Monferrà, S., \& Mustilli, M. (2018). Does corporate social responsibility help the survivorship of SMEs and large firms? Global Finance Journal, 100402.

Godfrey, P. C. (2005). The relationship between corporate philanthropy and shareholder wealth: A risk management perspective. Academy of management review, 30(4), 777-798.

Godfrey, P. C., Merrill, C. B., \& Hansen, J. M. (2009). The relationship between corporate social responsibility and shareholder value: An empirical test of the risk management hypothesis. Strategic Management Journal, 30(4), 425-445.

Harjoto, M., \& Laksmana, I. (2018). The impact of corporate social responsibility on risk taking and firm value. Journal of Business Ethics, 151(2), 353-373.

Hoi, C. K., Wu, Q., \& Zhang, H. (2013). Is corporate social responsibility (CSR) associated with tax avoidance? Evidence from irresponsible CSR activities. The Accounting Review, 88(6), 2025-2059.

Hsu, F. J., \& Chen, Y.-C. (2015). Is a firm's financial risk associated with corporate social responsibility? Management decision.

Jensen, M. C., \& Meckling, W. H. (1976). Theory of the firm: Managerial behavior, agency costs and ownership structure. Journal of financial economics, 3(4), 305-360.

Jiraporn, P., Jiraporn, N., Boeprasert, A., \& Chang, K. (2014). Does corporate social responsibility (CSR) improve credit ratings? Evidence from geographic identification. Financial Management, 43(3), 505-531.

Jo, H., \& Na, H. (2012). Does CSR reduce firm risk? Evidence from controversial industry sectors. Journal of Business Ethics, $110(4), 441-456$.

Khan, N., \& Malik, Q. A. (2020). Impact of corporate socilal responsibility on firm performance mediating role of investment inefficiency. International Transaction Journal of Engineering, Management, \& Applied Sciences \& Technologies, 11(12).

Khan, N., \& Saghir, A. (2020). Corporate Social Responsibility and Firm Performance: Evidence from Pakistan. International Review of Management and Business Research, 09(04).

Kim, Y., Li, H., \& Li, S. (2014). Corporate social responsibility and stock price crash risk. Journal of Banking \& Finance, $43,1-13$.

Krüger, P. (2015). Corporate goodness and shareholder wealth. Journal of financial economics, 115(2), 304-329.

Lin, C.-H., Yang, H.-L., \& Liou, D.-Y. (2009). The impact of corporate social responsibility on financial performance: Evidence from business in Taiwan. Technology in Society, 31(1), 56-63.

Lins, K. V., Servaes, H., \& Tamayo, A. (2017). Social capital, trust, and firm performance: The value of corporate social responsibility during the financial crisis. The journal of finance, 72(4), 1785-1824.

Lu, W., Chau, K., Wang, H., \& Pan, W. (2014). A decade's debate on the nexus between corporate social and corporate financial performance: a critical review of empirical studies 2002-2011. Journal of Cleaner Production, 79, $195-206$.

Mackey, A., Mackey, T. B., \& Barney, J. B. (2007). Corporate social responsibility and firm performance: Investor preferences and corporate strategies. Academy of management review, 32(3), 817-835.

Mitnick, B. M. (1975). The theory of agency. Public Choice, 24(1), 27-42.

Platt, H. D., \& Platt, M. B. (2002). Predicting corporate financial distress: reflections on choice-based sample bias. Journal of economics and finance, 26(2), 184-199.

Pradhan, A. K., \& Nibedita, B. (2019). The determinants of corporate social responsibility: Evidence from Indian Firms. Global Business Review, 0972150918814318.

Pyo, G., \& Lee, H.-Y. (2013). The association between corporate social responsibility activities and earnings quality: Evidence from donations and voluntary issuance of CSR reports. Journal of Applied Business Research (JABR), 29 (3), 945-962.

Sarwar, B., Xiao, M., Husnain, M., \& Naheed, R. (2018). Board financial expertise and dividend-paying behavior of firms. Management decision.

Shen, C.-H., Wu, M.-W., Chen, T.-H., \& Fang, H. (2016). To engage or not to engage in corporate social responsibility: Empirical evidence from global banking sector. Economic Modelling, 55, 207-225.

Shleifer, A., \& Vishny, R. W. (1992). Liquidation values and debt capacity: A market equilibrium approach. The journal of finance, 47(4), 1343-1366.

Sun, W., \& Cui, K. (2014). Linking corporate social responsibility to firm default risk. European Management Journal, 32(2), 275-287.

Sun, Y., Duong, H. N., \& Singh, H. (2014). Information Asymmetry, Trade Size, and the Dynamic Volume-Return Relation: Evidence from the Australian Securities Exchange. Financial Review, 49(3), 539-564.

Taylor, G., Al-Hadi, A., Richardson, G., Alfarhan, U., \& Al-Yahyaee, K. (2019). Is there a relation between labor investment inefficiency and corporate tax avoidance? Economic Modelling.

Wang, K., Sewon, O., \& Claiborne, M. C. (2008). Determinants and consequences of voluntary disclosure in an emerging market: Evidence from China. Journal of International Accounting, Auditing and Taxation, 17(1), 14-30.

Weber, M. (2008). The business case for corporate social responsibility: A company-level measurement approach for CSR. European Management Journal, 26(4), 247-261. 
Yang, A. S., \& Baasandorj, S. (2017). Exploring CSR and financial performance of full-service and low-cost air carriers. Finance Research Letters, 23, 291-299.

Yang, S.-L., Chang, A., Chen, Y.-H., \& Shiu, Y.-M. (2019). Can country trade flows benefit from improved corporate social responsibility ratings? Economic Modelling, 80, 192-201.

Zheng, Y., Wang, Y., \& Jiang, C. (2019). Corporate Social Responsibility and Likelihood of Financial Distress.

Zmijewski, M. E. (1984). Methodological issues related to the estimation of financial distress prediction models. Journal of accounting research, 59-82.

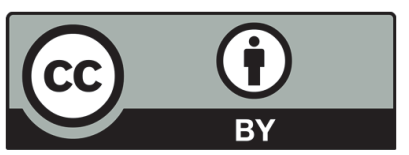

(C) 2021 by the authors; licensee Growing Science, Canada. This is an open access article distributed under the terms and conditions of the Creative Commons Attribution (CC-BY) license (http://creativecommons.org/licenses/by/4.0/). 